Review

\title{
Synthetic Nitroimidazoles: Biological Activities and Mutagenicity Relationships
}

\begin{abstract}
Alka MITAL
Department of Pharmaceutical Technology, National Institute of Pharmaceutical Education and Research, Sector 67, S. A. S. Nagar-160062, Punjab, India

E-mail: alkamital@gmail.com

Sci Pharm. 2009; 77: 497-520

doi:10.3797/scipharm.0907-14

Published: $\quad$ August $12^{\text {th }} 2009$

Accepted: $\quad$ August $11^{\text {th }} 2009$

Received: $\quad$ July $20^{\text {th }} 2009$

This article is available from: http://dx.doi.org/10.3797/scipharm.0907-14

(c) Mital; licensee Österreichische Apotheker-Verlagsgesellschaft m. b. H., Vienna, Austria.

This is an Open Access article distributed under the terms of the Creative Commons Attribution License (http://creativecommons.org/licenses/by/3.0/), which permits unrestricted use, distribution, and reproduction in any medium, provided the original work is properly cited.
\end{abstract}

\begin{abstract}
Parasitic and bacterial infections affecting the gastrointestinal tract represent a significant cause of morbidity and mortality worldwide. Nitroheterocyclic drugs have been available since the early 1960s for the treatment of anaerobic protozoa. The application of these drugs has widened and they are presently used to treat anaerobic pathogenic bacteria and protozoa. 5-nitroimidazoles are a well-established group of antiprotozoal and antibacterial agents that inhibit the growth of both anaerobic bacteria and certain anaerobic protozoa, such as Trichomonas vaginalis, Entamoeba histolytica and Giardia lamblia. The important antibacterial and antiprotozoal activities of nitroimidazoles are associated with reductive metabolism that has led to considerable interest in nitroimidazole reduction chemistry and the synthesis of new, highly effective drugs. The present review provides a brief account of various biological activities exhibited by synthetic nitroimidazole derivatives as well as their structure-mutagenicity relationships.
\end{abstract}

\section{Keywords}

Antibacterial - Antifungal - Antimycobacterial - Trypanocidal - Anti-HIV activity • Antileishmanial agents 


\section{Introduction}

Nitroheterocyclic compounds have a wide variety of applications, ranging from food preservatives to antibiotics. Nitroimidazoles have therapeutic uses as anaerobic antibacterials and antiprotozoal agents. 5-nitroimidazoles are a well-established group of antiprotozoal and antibacterial agents [1]. The antimicrobial activity of these chemotherapeutic agents inhibits the growth of both anaerobic bacteria and certain anaerobic protozoa such as Trichomonas vaginalis, Entamoeba histolytica and Giardia lamblia [2]. They have other interesting biological activities of therapeutic potential such as, radiosensitizers in treatment of cancer [3-5], control of fertility [6], and antitubercular therapy [7, 8]. 5-nitroimidazole derivatives have been tested in cell-based assays and in enzyme assays against HIV-1 recombinant reverse transcriptase [9, 10]. 2-Nitroimidazoles play a major role as bioreductive markers for tumour hypoxia, as radiosensitizers [11-13], and some also demonstrate antiprotozoan activity [14]. Some dinitro and mono nitroimidazole derivatives have been predicted as notable radiosensitizers, antiprotozoal and antibacterial or antiepileptic agents [15].

\section{Antibacterial agents}

The introduction of nitroheterocyclic drugs in the late 1950s and the 1960s heralded a new era in the treatment of infections caused by gram-negative and -positive bacteria and a range of pathogenic protozoan parasites. The antibiotic azomycin, a 2-nitroimidazole, isolated from a streptomycete, was the first active nitroimidazole to be discovered [16], which acted as the main impetus for the systematic search for drugs with activity against anaerobic protozoa. This led to the synthesis of the 5-nitroimidazole, metronidazole (1-hydroxyethyl-2-methyl-5-nitroimidazole, MTZ) and the demonstration of its activity against $T$. vaginalis [17]. Subsequently, MTZ was shown to cure giardiasis [18], amoebiasis [19], and Balantidium infections [20]. MTZ is most widely used in the treatment of anaerobic protozoan parasitic infections caused by $T$. vaginalis, $G$. duodenalis, and $E$. histolytica [21]. Metronidazole, tinidazole and ornidazole are the main synthetic agents of therapy for invasive amoebiasis (Figure 1) [22, 23]. The highly selective effect of these drugs is due to reduction of these drugs by nitroreductase enzymes resulting in the formation of highly reactive free radical species $[24,25]$. Although there is no carcinogenicity or mutagenicity of metranidazole in human beings [26], it has been shown to be mutagenic in bacteria and carcinogenic in rodents [27-29]. Depending on the nature of substituents and the position of the nitro group, the nitroimidazole derivatives can show various pharmacological activities [30]. The compounds with nitro group at position 4 are usually less active than the corresponding 5-nitro derivatives.

Tinidazole and ornidazole have different side chains at the 1 position, do not differ markedly in their antimicrobial activity. Modifications at the 2 position, however, are known to interfere with both the activity and the microbial spectrum [31]. Compound GO 10213 [1-methylsulfonyl-3-(1-methyl-5-nitro-2-imidazolyl)-2-imidazolidinone], which has an imidazolidinone ring structure at the 2 position [32], exerts stronger antitrichomonal activity than MTZ (Figure 1) [33, 34]. GO 10213 is highly active against anaerobic bacteria, even more than metronidazole but less than niridazole. Thus, the modification of the 5-nitroimidazole at the 2 position increases not only its antitrichomonal activity but also its antibacterial activity [33,34]. Although GO 10213 may be more active than MTZ, the imidazolidinone ring in this compound has been shown to be more carcinogenic than the nitro- 
imidazole ring, making it less attractive therapeutically [35]. Various 5-(1-methyl-5-nitro-2imidazolyl)-4H-1,2,4-triazoles were synthesized and tested in vitro for their antibacterial and antifungal activities. Few compounds exhibited significant effects against Bacillus subtilis at MIC ranges of $0.5-1 \mu \mathrm{g} / \mathrm{ml}$ and moderate effects against Staph. aureus [36].

The nitroimidazole compound 1, 1-methyl-2-methylsulfonyl-4-nitroimidazole, is an antiprotozoal and bactericidal compound with the unique and surprising property of being totally non-mutagenic and thus of a much higher degree of safety than is found with other nitroimidazoles (Figure 1) [32,37]. The invention of Miwa et al., relates to the nonmutagenic 1,2-disubstituted-4-nitroimidazole compounds with structure 2, useful as antiprotozoal agents (Figure 1) [38]. The compounds are 1,4-dimethyl-5-nitro-1H-imidazol2-yl methylcarbamate, 1,4-dimethyl-2-(2-hydroxyethyl)-5-nitroimidazole, 1,2-dimethyl-4(2-hydroxyethyl)-5-nitroimidazole, and pivaloyl esters. These novel compounds are not mutagenic in Ames strain TA100, and are highly potent against protozoal diseases. They also demonstrated that 1,2,4-substituted 5-nitroimidazoles are potent antiprotozoal and/or antibacterial agents with little or no mutagenic and drug residue level problems.

There was an attempt to differentiate among the structural elements contributing to mutagenicity and antitrichomonal activities as a basis for the rational design of safer nitroimidazoles [39]. Walsh et al., presented two approaches for developing nonmutagenic 5-nitroimidazoles based on knowledge of the likely mechanisms by which reactive intermediates are metabolically formed [40]. These approaches are the incorporation of a substituent at the C-4 position of the imidazole ring and the addition of readily oxidizable functionalities (gallate ester derivatives) into the molecule. These structural features revealed that the addition of a 4-substituent significantly reduced or eliminated the mutagenicity, and always reduced the in vitro antitrichomonal activity.

Differently substituted 2-hydroxyaryl-(1-methyl-5-nitro-1H-imidazol-2-yl)methanols, 3, 4 with substituted phenolic rings in the ortho and/or para positions and containing bulky and strong lipophilic groups such as a t-butyl group in the carbocyclic ring have been reported in the patents [41, 42] for their antimicrobial activity and lack of mutagenicity (Fig. 1) [43].

The antimicrobial profile of a new nitroimidazole derivative EU 11100 (5-nitro-1-methylimidazol-2-yl-(2-hydroxy-3-tert-butylphenyl)carbinol) has been studied by Dubini et al., (Figure 1) [44]. The in vitro activity has been evaluated against both aerobic and anaerobic bacteria, T. vaginalis, and mycetes, under suitable experimental conditions. The compound was compared with ampicillin against aerobic bacteria; with MTZ against anaerobic bacteria, lactobacilli and $T$. vaginalis; with nistatin and econazole against candida and with econazole and bifonazole against filamentous fungi. This derivative has been shown to be moderately active against some anaerobic bacteria belonging to both the Gram-positive and Gram-negative groups. Its inhibitory activity against $T$. vaginalis was similar to that of metronidazole [44].

A new series of substituted (Z)-2-arylidene-3(2H)-benzofuranones bearing 1-methyl5-nitroimidazole $\mathbf{5}$ or 4-nitroimidazole $\mathbf{6}$ were synthesized and assayed for their antibacterial activity against Gram-positive and Gram-negative bacteria (Fig. 1) [45]. Most of the 5-nitroimidazole analogues showed a remarkable inhibition of a wide spectrum of Gram-positive bacteria (Streptococcus aureus, S. epidermidis, MRSA, and Bacillus subtilis) and Gram-negative Klebsiella pneumoniae, whereas 4-nitoimidazole analogues 
exhibited no effect against selected bacteria. The quantitative structure-activity relationship investigation was applied to find a correlation between different physicochemical parameters of the compounds studied and their biological activity. Their antibacterial activity, suggests that possibly negative charge of $-\mathrm{NO}_{2}$ group on $\mathrm{C}-5$ of imidazole and partial charge on carbonyl oxygen in benzofuran are necessary for action. Moreover, there is a limited space available for this moiety of benzofuran system, thus the bulkier substituted analogues $7\left(R=5-\mathrm{Br}, 5-\mathrm{CH}_{3}\right)$ were inactive (Figure 1). Changing the position of the substituent on the benzofuran appears to have little influence on the antibacterial activity. Khabnadideh et al., synthesized a series of alkylimidazole 8 and investigated the relationship between the length of the alkyl chain and its antibacterial activity (Fig. 1) [46]. The compound 8 were investigated for antibacterial activity against Staphylococcus aureus, Pseudomanas aeruginosa and Escherichia coli. Several compounds showed significant in vitro activity against $E$. coli, $S$. aureus and $P$. aeruginosa. Antibacterial activity of 1-alkylimidazoles increases as the number of carbons in the alkyl chain rises to nine and then decreases. So 1-nonylimidazole 9 is the most effective compound (Figure 1), as it has the lowest MIC (minimum inhibitory concentration) and MBC (minimum bactericidal concentration) (MIC S. aureus $=10 \mu \mathrm{g} / \mathrm{ml}$; MBC $S$. aureus $=19 \mu \mathrm{g} / \mathrm{ml}$; MIC $P$. aeruginosa $=39 \mu \mathrm{g} / \mathrm{ml}$; MBC $P$. aeruginosa $=78 \mu \mathrm{g} / \mathrm{ml}$; MIC E. coli $=$ $19 \mu \mathrm{g} / \mathrm{ml}$; MBC E. coli $=39 \mu \mathrm{g} / \mathrm{ml}$ ).

The antiparasitic activity of nitroimidazoles 10 bearing an arylsulfonylmethyl group was assessed against $T$. vaginalis, and the in vitro cytotoxicity was evaluated on human monocytes and the mutagenicity was determined by the Salmonella mutagenicity assay (Figure 1) [47]. Molecules, bearing an additional methyl group on the 2-position, showed a lower mutagenicity than metronidazole. All the tested molecules were found to be mutagenic in the Salmonella mutagenicity assay using the most sensitive strain TA100 $[48,49]$. Moreover, three derivatives were characterized by a low mutagenicity and an efficient antitrichomonal activity. The methyl group at the 2-position and the arylsulfonylmethyl group at the 4-position of imidazole ring modulated the nitro reduction at the 5-position as in $\mathbf{1 0}$. They have shown that the replacement of the methyl group at the 2-position by a lactam group could double the mutagenicity of metronidazole [50]. In this study, the methyl group at the 2-position combined with the arylsulfonylmethyl group at the 4-position lowered the $\mathrm{MP}_{\mathrm{TA} 100}$ of dimetridazole, metronidazole and secnidazole series [47]. A good correlation was demonstrated between the antiprotozoal activity and the mutagenicity for these molecules which reflects their ability to damage DNA through covalent binding and induction of DNA breaks [51]. They were characterized by a low mutagenicity and high antiparasitic activity. Although the mechanism of action explaining their biological activity remains to be elucidated, these newly synthesized compounds allow the disconnection between mutagenicity and biological activity for the first time. This approach offers the possibility of synthesizing new and potentially safer 5-nitroimidazoles.

A series of $N$-[5-(5-nitro-2-heteroaryl)-1,3,4-thiadiazol-2-yl]thiomorpholine derivatives were synthesized and evaluated for in vitro anti-Helicobacter pylori activity (Figure 1) [52]. Nitrofuran analog 11 containing thiomorpholine S,S-dioxide moiety was the most potent compound displaying very strong activity at $8 \mathrm{mg} /$ disc (inhibition zone diameter $>40 \mathrm{~mm}$ ) against both MTZ-sensitive and resistant strains. Among nitrothiophenes, compound 12 showed moderate activity and compound 13 showed strong activity against $H$. pylori at three different concentrations (Figure 1). 
<smiles>Cc1ncc([N+](=O)[O-])n1CCO</smiles>

Metronidazole<smiles>CO[N+](=O)[O-]</smiles>

GO 10213<smiles>COS(=O)(=O)CCn1c([N+](=O)[O-])cnc1C</smiles>

Tinidazole<smiles>O=C1NCCN1c1ncc([N+](=O)[O-])s1</smiles>

Niridazole<smiles>Cc1ncc([N+](=O)[O-])n1CC(O)CCl</smiles>

Ornidazole<smiles>CCn1c([N+](=O)[O-])cnc1C(O)c1cc(OC)cc(I)c1O</smiles><smiles>COS(=O)(=O)c1nc([N+](=O)[O-])cn1C</smiles>

1<smiles>[R]/C=c1/o/c(=C\c2ncc([N+](=O)[O-])n2C)c(=O)c2ccccc12</smiles>

5

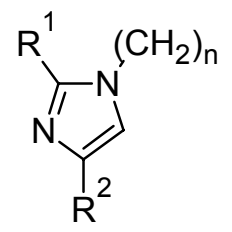

8: $\mathrm{R}_{1}=\mathrm{H}, \mathrm{CH}_{3}, \mathrm{R}_{2}=\mathrm{H}, \mathrm{NO}_{2}$<smiles>O=[N+]([O-])c1ccc(-c2nnc(N3CCS(=O)(=O)CC3)s2)o1</smiles>
11<smiles>[R]n1cc([N+](=O)[O-])nc1[SeH]</smiles>

2<smiles>[R]c1cccc(C(O)c2ncc([N+](=O)[O-])n2C)c1O</smiles>

3<smiles>[R]c1cccc(C(c2cccc([R])c2O)c2ncc([N+](=O)[O-])n2C)c1O</smiles>

4<smiles>[R]/C=c1/o/c(=C\c2ncc([N+](=O)[O-])n2C)c(=O)c2ccccc12</smiles>

6<smiles>[R][R]([H])c1nc(CS(=O)(=O)c2ccc([Y])cc2)c([N+](=O)[O-])n1[R]</smiles>

10:

$\mathrm{X}=\mathrm{H}, \mathrm{CH}_{3}, \mathrm{Cl}, \mathrm{Br}, \mathrm{F}$ $\mathrm{R}_{1}, \mathrm{R}_{2}=\mathrm{H}, \mathrm{CH}_{3},-\left(\mathrm{CH}_{2}\right)_{2} \mathrm{OH}$<smiles>O=[N+]([O-])c1ccc(-c2nnc(N3CCSCC3)s2)s1</smiles>

12<smiles>O=[N+]([O-])c1ccc(-c2nnc(N3CC[Se]CC3)s2)s1</smiles>

13

Fig. 1. Antibacterial agents

\section{Antifungal nitroimidazoles}

The imidazoles are a class of antifungal azole derivatives having a broad spectrum of activities both in vitro and in vivo. Four 5-nitroimidazoles derivatives, satranidazole, S75 $0400 \mathrm{~A}$, flunidazole and ronidazole were tested and found to be more active than MTZ, the 
drug commonly used to treat infections caused by Blastocystis hominis in humans [53]. Ketoconazole and iodoquinol have been reported to have therapeutic activity in infections caused by $B$. hominis, and were found to be less active than MTZ.

Some new nitroimidazole derivatives bearing a 1,2,4-triazolylthioethyl, 1,2,4-triazolylthiopropyl or $\mathrm{N}, \mathrm{N}$-disubstituted dithiocarbamoyl-propyl residue at $\mathrm{N}-1$ were synthesized and evaluated for in vitro antibacterial and antifungal activity (Figure 2) [54]. Although not as active as the standard ampicillin, compound 14 were found to be active against $S$. aureus ATCC 6538 and/ or S. epidermidis ATCC 12228 where ornidazole was devoid of activity. The most active compound was 15 (antifungal activity against Trichophyton tonsurans NCPF 245; MIC $=3 \mu \mathrm{g} / \mathrm{ml}$ ) exerting about one half the activity of ornidazole. A panel of antifungal and antihelmintic drugs was tested for activity against Mycobacterium tuberculosis (M. tb) in vitro. Antifungal drugs, miconazole, 2-nitroimidazole, clotrimazole, and the antihelmintic drug niclosamide were found to have significant antituberculosis activity, with MICs between 1 and $10 \mu \mathrm{g} / \mathrm{ml}$ [55]. Niclosamide and 2-nitroimidazole also had activity against stationary phase tubercle bacilli.<smiles>[R]n1c(SCC(O)Cn2c([N+](=O)[O-])cnc2C)nnc1-c1ccco1</smiles>

14<smiles>[X]c1ccc(C(=O)Cn2c([R])nc([R])c2[N+](=O)[O-])cc1</smiles><smiles>Cc1ncc([N+](=O)[O-])n1CC(O)CSC(=O)N1CCN(C(=O)c2ccccc2)CC1</smiles>

16

$\mathrm{R}_{1}=\mathrm{H}, \mathrm{CH}_{3}$ $\mathrm{R}_{2}=\mathrm{NO}_{2}$, morpholine, pyrrolidine, piperidine $\mathrm{N}$-methyl $\mathrm{X}=\mathrm{H}, \mathrm{Cl}$

Fig. 2. Antifungal agents

Some derivatives have been synthesized by treating 4,5-dinitro- and 2-methyl4,5-dinitroimidazoles with epoxypropane, epichlorohydrin or phenacyl bromide and tested for their antioxidant and antifungal properties against fungi species Sclerophoma pityophila [56]. The nitro group in N-substituted 4,5-dinitro- and 2-methyl-4,5-dinitroimidazoles has been replaced with primary and secondary amines to afford 4-amino-5-nitroimidazole derivatives. Nearly all of them have shown significant antioxidant activity in comparison with that of tocopherol, which is used as a reference substance. Amongst the most active derivatives 16, bearing chlorine atom in 2-hydroxypropyl and 2-oxopropyl chains or phenacyl group at $\mathrm{N}-1$ position of the imidazole ring (Figure 2), two compounds have very strong fungistatic activity against $S$. pityophila. High effectiveness was induced by the displacement of nitro group at 4-position on the imidazole ring to morpholine or piperidine and by the presence of a chlorine atom at 4-position on the phenyl ring. 


\section{Antimycobacterial nitroimidazoles}

One of the first reports to note the antimycobacterial activity of 2-nitroimidazoles compounds were a series of compounds synthesized with a variety of substituents at the 1- and 5-positions [57]. They were tested for activity against a panel of Gram-negative and Gram-positive organisms, as well as fungi. The majority of compounds with alkyl, amide, or alcohol substituents were found to be inactive against all organisms tested. There was improvement in activity, however, when the 5-substituent was replaced with a vinyl group. A four-fold increase in $M$. tb activity occurred when the $\mathrm{N}-1$ substituent was changed from methyl to ethyl. Activity was the highest against $M$. tb when the $\mathrm{N}-1$ substituent was ethyl and the 5-vinyl group was left unsubstituted. These vinyl substituted 2-nitroimidazoles were explored further in a subsequent report by the same group [58] and the best activity against this strain $(2 \mu \mathrm{g} / \mathrm{ml})$ was for 1-methyl-2-nitro-5-(2-nitrohex-1-enyl)-1H-imidazole, a compound with a vinyl group substituted with both an $n$-butyl group and a second nitro group. Several series of 2-nitro and 2-aminoimidazoles with hydrophilic substitutions at the 5 -positions such as oximes and hydrazones were synthesized and tested for antibacterial activity [59-61]. Most of these compounds had moderate activity against M. to (10-200 $\mu \mathrm{g} / \mathrm{ml}$ ), but they displayed enhanced activity against many other organisms. The most potent compound against $M$. tb $(5 \mu \mathrm{g} / \mathrm{ml})$ was bearing an $n$-decyl substituted oxime at the 5 -position of the imidazole ring. The authors noted that lipophilic substituents at the 5-position increased activity against Gram positive organisms, including $M$. tb.

4- and 5-nitroimidazoles have been the subject of significant efforts to optimize antitubercular activity. One particular class of nitroimidazoles, containing an oxazole (or oxazine) ring structure fused to the imidazole, has shown particular promise. These compounds were originally discovered to create novel dinitroimidazoles that might have improved characteristics as radiosensitizers. Dinitroimidazoles, nitroimidazo[2,1b]oxazoles were synthesized by reaction of the unsubstituted dinitro precursor with oxiranes, spontaneous cyclization, accompanied by loss of the 2-nitro group [62]. These compounds were later found to have potent antitubercular activity and analogued by chemists from Hindustan Ciba-Geigy, India for antitubercular optimization [7,63]. Three discrete series of structural analogs were explored: 4-nitroimidazo [2,1-b]oxazoles, 5-nitroimidazo[2,1-b] oxazoles, and 4-nitroimidazo-1-ethanols. The uncyclized nitroimidazo-1-ethanols were not as active as the corresponding imidazo[2,1-b]oxazoles. The lead compound was 17 a, with a methyl group on the 2-position of the imidazo-oxazole ring, and a MIC of $1.95 \mu \mathrm{g} / \mathrm{ml}$ against $M$. tb H37Rv (Figure 3). Variations in the imidazo[2,1-b]oxazole series with a single substitution at the 2-position, increasing chain length slightly (to ethyl to give compound CGI 17341, 17b) or adding a single halogen atom (17c) increased in vitro activity dramatically (30 and 16-fold, respectively). Replacement of the methyl group with a benzene ring (17d) increased activity only slightly (2-fold) while replacement with long, straight-chain alkyl groups decreased in vitro activity.

CGI 17341 (2-ethyl-5-nitro-2,3-dihydroimidazo[2,1-b][1,3]oxazole) is a novel lipophilic and orally active representative of the 5-nitroimidazole series of antimicrobial agents. This nitroimidazooxazole derivative is a promising novel antituberculosis compound with potent in vitro and in vivo activities [7,63], but is not developed because of its mutagenic properties. CGI 17341 inhibited the drug-susceptible and multi-drug-resistant strains of $M$. $t b$ and had no cross-resistance with isoniazid, rifampin, streptomycin, or ethambutol. While 
its in vitro activity against $M$. tb was comparable to those of isoniazid and rifampin, it was superior to those of streptomycin, ciprofloxacin or norfloxacin, and oxazolidinone DuP 721. Bicyclic nitroimidazoles such as PA-824 and OPC-67683 are currently in clinical development as a promising new class of therapeutics for tuberculosis (Figure 3) [64]. CGI-17341, OPC-67683, both nitroimidazo-oxazoles, and PA-824, a nitroimidazo-oxazine, have activity against aerobic and anaerobic populations of $M$. tb $[63,65,66]$. PA-824 has many attractive characteristics as a TB therapy, most notably its novel mechanism of action, its activity in vitro against all tested drug-resistant clinical isolates, and its activity as both a potent bactericidal and a sterilizing agent in mice. PA-824 shows no evidence of mutagenicity in genotoxicity studies, no significant cytochrome P450 interactions, and is inactive against a broad range of Gram-positive and Gram-negative bacteria. OPC-67683 had both inhibitory activity on mycolic acid biosynthesis and potent in vitro activity against $M$. $t b$, as indicated by its low MIC range across many strains, including MDR-TB [65]. The $\mathrm{IC}_{50}$ values of OPC-67683 for mycolic acid subclasses were lower than those of isoniazid (INH), and these results correlated well with the in vitro anti-tubercular activity of OPC67683 and INH. The anti-tubercular activity of nitro-imidazooxazole derivatives correlated well with their inhibitory activity against mycolic acid biosynthesis [65]. Thus they concluded that the inhibitory activity of OPC-67683 against mycolic acid synthesis was a mechanism of action attributable to killing mycobacteria at least as potently as INH. PA824 has remarkably reduced mutagenicity compared with its parent nitroimidazole compound, CGI-17341, and it has recently been reported that PA-824 is not mutagenic in the Ames test and does not seem to be metabolized by cytochrome P450 into potentially carcinogenic substances [67]. This suggested the possibility that its mutagenic activity will continue to be the major obstacle to its development as an anti-TB drug.

The anti-tuberculosis activity of various imidazole derivatives has been reported [68, 69]. Among 1-aryl-4-nitroimidazoles without nitro groups at 1-aryl substituent only 1-(4chlorophenyl)-2-methyl-4-nitroimidazole 18a demonstrated sufficient activity (99\% of inhibition at $6.25 \mu \mathrm{g} / \mathrm{ml}$ ), others derivatives were inactive though bromo derivatives $\mathbf{1 8 b}$ were characterized by $76 \%$ and $85 \%$ inhibition, respectively (Figure 3 ) [70]. It was clear that electron-donating substituent on 1-nitrogen atom in C-nitroimidazoles diminishes inhibition activity of the compounds. Surprisingly, it also appears that 2-methyl-4nitroimidazoles are more active than 4-nitroimidazoles. Tuberculosis inhibition activity and cytotoxicity results of these derivatives were not better or at least similar to the control drugs INH and rifampicin (RMP).

Two series of 2-(5-nitro-2-furyl)- and 2-(1-methyl-5-nitro-1H-imidazol-2-yl)-5-propyl, allyl and propargyl)thio-1,3,4-thiadiazoles (19a-f) and 2-(5-nitro-2-furyl)- and 2-(1-methyl-5nitro-1H-imidazol-2-yl)-5-(nitrobenzyl)thio-1,3,4-thiadiazole derivatives (20a-f) were synthesized and evaluated against M. tb (Figure 3) [71]. Among the nitrobenzylthio derivatives $(20 a-f)$, all the ortho, meta and para nitrobenzyl isomers in the nitrofuran series exhibited good antituberculosis activity, while the corresponding nitroimidazole analogues were completely inactive (Inhibition=0\%). The compounds that bear a primary alkylthio substitution, displayed good antituberculosis activities, in the following order: $n$-propyl > ethyl > methyl $(\mathrm{MIC}=1.56-6.25 \mu \mathrm{g} / \mathrm{ml})$ [72]. Some nitroimidazole and nitrofuran derivatives have been also claimed to possess in vitro antibacterial, antifungal and antituberculosis activities [54]. 
<smiles>CCC1Cn2cc(N=O)nc2O1</smiles>

17b, CGI-17341<smiles>[R]C1CC2N=C([N+](=O)[O-])N=C2O1</smiles>

17a: $\mathrm{R}=\mathrm{CH}_{3}$,

17b: $\mathrm{R}=\mathrm{C}_{2} \mathrm{H}_{5}, \mathrm{CGI}-17341$

17c: $\mathrm{R}=\mathrm{CH}_{2} \mathrm{Cl}$

$17 \mathrm{~d}: \mathrm{R}=\mathrm{Ph}$<smiles>CC(F)(F)Oc1ccc(OC2CCN(c3ccc(OC[C@@]4(C)Cn5ccnc5O4)cc3)CC2)cc1</smiles>

OPC-67683<smiles>[R]c1ccc(-n2cc([N+](=O)[O-])nc2[R])cc1</smiles><smiles>[R]Bc1nnc([AlH])s1</smiles>

$\mathrm{R}=n$-propyl, aryl, or propargyl<smiles>Cc1ccc([N+](=O)[O-])o1</smiles>

$19 a-f$<smiles>O=[N+]([O-])c1cn2c(n1)OC[C@@H](OCc1ccc(OC(F)(F)F)cc1)C2</smiles>

PA-824 18a: $\mathrm{R}_{1}=\mathrm{CH}_{3}, \mathrm{R}_{2}=\mathrm{Cl}$ 18b: $\mathrm{R}_{1}=\mathrm{H}, \mathrm{CH}_{3}, \mathrm{R}_{2}=\mathrm{Br}$

Fig. 3. Antimycobacterial agents

\section{Trypanocidal nitroimidazoles}

The nitroimidazole-thiadiazole derivative CL64855 (2-amino-5-(1-methyl-5-nitro-2imidazolyl)-1,3,4-thiadiazole, 5-nitromegazol) has a pronounced trypanocidal activity [7375] which may be due to the triggering of radical production by the compound (Figure 4) $[74,76,77]$. Benznidazole was found mutagenic in Salmonella $[78,79]$. The location of the nitro group in position 4 makes the nitro heterocyclic compounds (such as 4-nitromegazol) totally inactive against parasite (Figure 4) [77]. The treatment with 5-nitromegazol entails the production of reactive oxygen species in aerobic conditions [80], it can induce redox cycling which explains its toxic effects, through the production of superoxide radical anion and then hydroxyl radicals [81], that are highly damaging for cellular structures. Most nitroimidazoles are mutagenic in bacteria, and this mutagenicity has been attributed to nitroreductases present in these organisms. It has been argued that the lower capacity of mammalian cells to perform nitro reduction decreases the genotoxic risk of 5-nitromegazol. However, some studies $[82,83]$ have demonstrated its genotoxicity in mammalian cells. Because of its efficacy against several strains of Trypanosoma cruzi of diverse sensitivity, 
it has a potential role in treatment of Chagas' disease. However, 5-nitromegazol has shown mutagenicity [84] according to the Ames assay. RO 150216, another nitroimidazole derivative, has been shown to be effective in inhibiting the culture growth of different strains of the African trypanosome [85], and in vivo using various animal models [80].

In an effort to synthesize imidazole analogs which retain biological but not toxic activities, a variety of new compounds with different substitutions on the bioisosteric imidazole and pyrazole structural frame were synthesized [48]. Structures bear substituents able to provide some variations in the lipophilic, steric and electronic properties of the molecules. In particular, substituents with increasing hydrophobic and steric properties, such as $-\mathrm{COOH},-\mathrm{COOCH}_{3},-\mathrm{CH}_{3},-\mathrm{CH}_{2} \mathrm{C}_{6} \mathrm{H}_{5}$ and $-\mathrm{CH}=\mathrm{CHC}_{6} \mathrm{H}_{5}$ groups were considered. Compounds were tested on a set of tester strains of Salmonella typhimurium; in particular, classical nitroreductase- or O-acetyltransferase deficient derivatives have been incorporated into the assay in order to study the metabolism and mutagenicity of nitro compounds $[86,87]$.<smiles>Cn1c([N+](=O)[O-])cnc1-c1nnc(N)s1</smiles>

CL64855, 5-Nitromegazol<smiles>Cn1cc([N+](=O)[O-])nc1-c1nnc(N)s1</smiles>

4-Nitromegazol<smiles>O=C(Cn1ccnc1[N+](=O)[O-])NCc1ccccc1</smiles>

Benznidazole<smiles>CN(C)CC(=O)Nc1ccc(OCc2cnc([N+](=O)[O-])n2C)cc1</smiles>

RO 150216<smiles>O=C(O)c1[nH]cnc1[N+](=O)[O-]</smiles>

21<smiles>COC(=O)c1[nH]cnc1[N+](=O)[O-]</smiles>

22<smiles>O=[N+]([O-])c1ncn(Cc2ccccc2)c1C=Cc1ccccc1</smiles>

23<smiles>O=[N+]([O-])c1nc[nH]c1/C=C/c1ccccc1</smiles>

24

Fig. 4. Trypanocidal agents

The structure-activity relationship study found that the following structural parameters are correlated with mutagenic potency: the presence of a methyl or a benzylic group on the imidazole ring, whereas the absence of a substituent in $\mathrm{N}_{1}$ or $\mathrm{N}_{3}$ leads to non-mutagenic compounds (derivative $\mathbf{2 1}$ and 22) or to a marked decrease in mutagenicity (85\% decrease with derivative 24 with respect to derivative 23) (Figure 4). The presence of bulky substituents, such as benzylic or styryl groups, on the imidazole ring leads to increased mutagenic activity, which implies that such substituents do not sterically hinder $\mathrm{NO}_{2}$ metabolic activation, which would have caused inhibition of the nitroreduction or DNA binding steps critical to mutagenicity. 
Some nitroimidazoles are reported as potent and selective histamine $\mathrm{H}-3$ receptor agonists [88, 89], mitogen-activated protein (MAP) kinases inhibitors [90], nitric-oxide synthase inhibitors [91] and antibacterial agents [92]. Furthermore, 5-nitro-substituted haloimidazoles, showed important biological activity as potential radiosensitizers [93] and other imidazole derivatives having 5-alkylsulfanyl residues exhibited remarkable antitumor activity [94].

\section{Anti-HIV active nitroimidazoles}

Non-nucleosides reverse transcriptase inhibitors (NNRTIs), a group of structurally diverse compounds, have been reported to directly inhibit the enzyme Reverse transcriptase (RT), which plays an essential and multifunctional role in the replication of HIV-1 and thus is considered to be an attractive target for inhibition of HIV-1 replication.

Al-Soud et al., reported the synthesis of new 5-substituted piperazinyl-4-nitroimidazole derivatives and their evaluation for anti-HIV activity [95]. The target was the synthesis of new 4-nitroimidazoles, leading to inhibition of HIV by inhibition of RT and reduction of the drug-resistance strains [95]. Compounds 25 and 26 were found to be most active among the tested compounds inhibiting HIV replication in cell culture (Figure 5). The structureactivity relationships of 4-nitroimidazole derivatives have suggested the importance of a piperazine group on the imidazole ring substituted by aliphatic carbonyl groups such as $\mathrm{COCH}_{2} \mathrm{Cl},-\mathrm{CO}\left(\mathrm{CH}_{2}\right)_{n} \mathrm{R}$ or sulphonamides for potent inhibitory activity against RT.<smiles>CCOC(=O)CSCC(=O)N1CCN(c2c([N+](=O)[O-])nc(CCCl)n2Cc2ccccc2)CC1</smiles>

25<smiles>[R]c1ccc(C(OCCn2c([N+](=O)[O-])cnc2C)c2ccccc2)c([R])c1[R]</smiles>

27<smiles>[R]c1ccc(C(OCCn2c([N+](=O)[O-])cnc2C)c2ccc(C)s2)c([R])c1[R]</smiles>

28

Fig. 5. Anti-HIV agents

1-[2-(Diarylmethoxy) ethyl]-2-methyl-5-nitroimidazoles (DAMNIs) is a novel family of HIV-1 non-nucleoside reverse transcriptase inhibitors (NNRTIs) active at submicromolar concentration [96, 97]. Replacement of one phenyl ring of 1-[2-(diphenylmethoxy) ethyl]-2methyl-5-nitroimidazole 27 with heterocyclic rings, such as 2-thienyl or 3-pyridinyl, led to novel DAMNIs with increased activity (Figure 5). In HIV-1 WT cell-based assay the racemic 1-\{2-[a-(thiophen-2-yl)phenylmethoxy]ethyl\}-2-methyl-5-nitroimidazole $28\left(\mathrm{EC}_{50}=\right.$ 
$0.03 \mu \mathrm{M}$ ) proved 5 times more active than compound 27. Docking experiments showed that the introduction of a chiral center would not affect the binding of both $(R)-28$ and $(S)$ 28. The internal scoring function of the Autodock program calculated the same inhibition constant $\left(K_{\mathrm{i}}=7.9 \mathrm{nM}\right)$ for the two enantiomers. Compounds $28\left(\mathrm{ID}_{50}=8.25 \mu \mathrm{M}\right)$ were found more active than efavirenz $\left(I_{50}=25 \mu \mathrm{M}\right)$ against the viral RT carrying the K103N mutation, suggesting for these compounds a potential use in efavirenz based anti-AIDS regimens.

\section{Antileishmanial agents}

A series of 1-[5-(1-methyl-5-nitro-1H-imidazol-2-yl)-1,3,4-thiadiazol-2-yl]-4-aroylpiperazines were synthesized and evaluated in vitro against Leishmania major [98]. The most active compound was 1-[(5-chloro-2-thienyl)...carbonyl]-4-[5-(1-methyl-5-nitro-1H-imidazol-2-yl)1,3,4-thiadiazol-2-yl] piperazine 29 with an $\mathrm{IC}_{50}$ value of $9.35 \pm 0.67 \mathrm{mM}$ against $L$. major promastigotes (Figure 6). In addition, this compound was effective against intracellular $L$. major and significantly decreased the infectivity index.

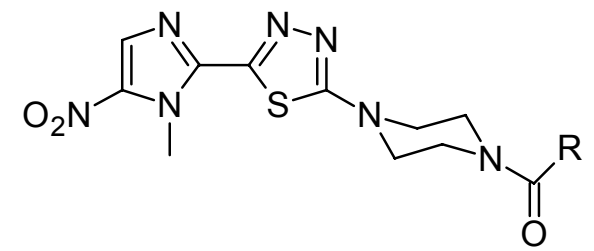

29: $\mathrm{R}=5$-Cl-thiophen-2-yl

Fig. 6. Antileishmanial agent

\section{Nitroimidazoles as radiosensitizers}

The 2-nitroimidazoles have been studied extensively for their use as radiosensitizers, hypoxic cytotoxins, and molecular markers of hypoxic regions in solid tumours [99-101]. Their selective hypoxic cytotoxicity and use as imaging agents for hypoxia are dependent on the bio-reduction of these compounds to reactive intermediates and the binding of these reductive species to intracellular macromolecules. Bio-reduction occurs only under extremely low oxygen tensions and, therefore, is selective for hypoxic regions [102]. In contrast, the use of 2-nitroimidazoles as radiosensitizers requires the intact compound to act as an oxygen mimic and potentiate the lethal effects of ionizing radiation in hypoxic but not aerobic cells [103].

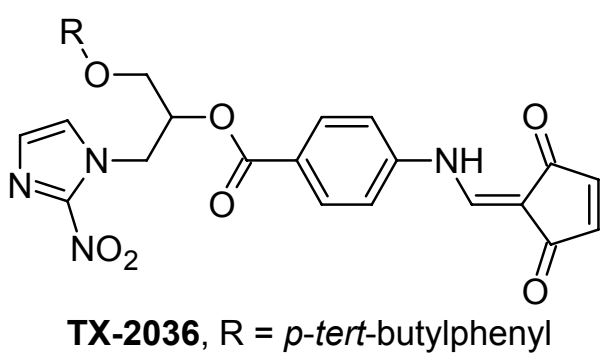

Fig. 7. Radiosensitizers 
Chiral 2-nitroimidazole derivatives containing a 2-aminomethylene-4-cyclopentene-1,3dione moiety were designed and synthesized as antiangiogenic hypoxic cell radiosensitizers [104]. All of these bifunctional derivatives proved to have activity as antiangiogenic hypoxic cell radiosensitizing agents and protein tyrosine kinase (PTK) inhibitory activities. TX-2036 was the most promising candidate for further development as an antiangiogenic hypoxic cell radiosensitizer (Figure 7).

2-Nitroimidazoles play a major role as bioreductive markers for tumour hypoxia and as radiosensitizers [11-13]. Several 2-nitroimidazoles with immunologically-identifiable sidechains have been described and conventional immuno-staining procedures can be used to locate their metabolites, bound to hypoxic cells in histological sections. Use of fluorescent immuno-reagents allows flow cytometric assessment of hypoxia and multiple colour fluorescent staining allows hypoxia to be correlated with other markers on a cell by cell basis. 2-nitroimidazole markers show considerable promise for clinical use in diagnosing hypoxia and allow rational application of hypoxia-related therapies [11].

\section{Mechanism of action of antibacterial nitroimidazoles}

MTZ and other nitroimidazoles are only toxic once they become reduced, and bioreduction requires low redox potential electron-transfer systems. In general, the single-electron reduction potential of nitroimidazoles lies outside the normal range of mammalian redox systems. One-electron reduction of nitroimidazoles leads to an unstable nitro radical anion that can either decompose to a nitrite anion and an imidazole radical or be further reduced by accepting a second electron [105]. The constant reduction of the nitroimidazole creates a favourable concentration gradient resulting in continuous influx of the drug across the cell membrane. In the presence of oxygen, the electron from the nitro radical anion can be abstracted by oxygen thereby regenerating the parent compound and forming superoxide by a process known as futile cycling. Two-electron reduction of nitroimidazoles leads to somewhat more stable nitroso intermediates. These intermediates may be the biologically active form of nitroimidazoles.

Unfortunately, the nitroso compounds are also 1000-fold more toxic to mammalian cells and 1000-fold more mutagenic in bacterial systems than the parental nitro compounds, supporting the concept that mammalian cells are not susceptible to nitroimidazoles primarily because of the lack of ability to reduce such molecules [106]. The mechanism of the trichomonicidal activity of metronidazole and other 5-nitroimidazoles appears to depend on the ferredoxin-mediated reduction of their nitro group, with generation of a reactive metabolite or metabolites which interact with DNA leading to a subsequent inhibition of nucleic acid and protein synthesis. Redox cycling of these compounds under aerobic conditions appears to be a detoxification reaction by inhibiting net reduction of the drugs, thereby inhibiting their uptake. On the other hand, redox cycling of nitrofurans or other compounds with more positive reduction potential results in formation of high steadystate concentrations of oxygen-derived metabolites that might be of toxicological significance. It seems likely that reduced metabolites of nitroimidazoles (perhaps through covalent binding to tissue macromolecules and/or thiols depletion) are also involved in the nitroimidazoles' toxic effects to animal tissues and in their mutagenic and carcinogenic action. 


\section{Toxicity, carcinogenicity and mutagenicity of nitroimidazoles}

MTZ is relatively well tolerated in animals, with an $L D_{50}$ of 1 to $5 \mathrm{~g} / \mathrm{kg}$ in rats in acute studies and no signs of chronic toxicity problems with doses up to $150 \mathrm{mg} / \mathrm{kg}$ in rats for up to 80 weeks. Monkeys appear to be less sensitive and even at doses up to $225 \mathrm{mg} / \mathrm{kg}$ showed no adverse events [107, 108]. In humans, MTZ is well tolerated, a fact reflected in the widespread use in pregnant women (MTZ is one of the top ten drugs used during pregnancy worldwide) [109].

Nitroimidazoles, as a group suffer from the property of being mutagenic and carcinogenic in a variety of experimental models [110]. Regarding mutagenicity, metronidazole is one of the best-investigated compounds of the nitroimidazoles. The mutagenicity of MTZ and other 5-nitroimidazoles has been studied in facultative anaerobic bacteria, particularly $S$. typhimurium and E. coli. The drug MTZ is mutagenic on bacteria, especially if base-pair tester strains are used and bacterial nitroreductases are present. The serum levels attained in man after intake of this drug are sufficient to cause mutations in bacteria. Furthermore, interaction with and binding to DNA occurs under anaerobic conditions and sometimes DNA breaks are observed. However, MTZ does not show mutagenic activity in mammalian cells in vitro; the micronucleus test is negative and chromosome aberrations are only found under anaerobic conditions. Surprisingly, no data are available concerning the mutagenicity of 5-nitroimidazoles in the anaerobic bacteria for which these drugs are the most potent antibiotics.

The nitro group reduction plays a key role in the overall activity and for the expression of mutagenicity and drug residue formation of nitroimidazoles. The prime biological target for nitro compounds is DNA, giving rise to concern regarding their mutagenic and carcinogenic toxicity. The compounds are converted to a common hydroxylamine intermediate, which is converted to an electrophilic nitrogen species, which reacts with DNA [111]. It is presumed that the separation of protozoal and genotoxic activities is not feasible, both of these properties being mediated through a common metabolic intermediate [112]. The mechanism of aerobic toxicity of 2-nitroimidazoles is due to the intracellular reactive oxygen species generated by the futile cycling of the parent compound, and cell sensitivity is modulated by the ability of the cell to detoxify these species [113]. However, experimental data supporting this mechanism of aerobic toxicity for 2-nitroimidazoles are limited [100].

Virtually every nitroimidazole that has ever been tested carefully has mutagenic potential in the Ames type assay for detecting bacterial DNA mutation by reversion. There has been a very substantial database of such activities and there are considerable structure-activity relationships that have been developed $[49,110]$. It is clear that mutagenic potential in the Ames assay varies over several orders of magnitude depending upon multiple factors including position of the nitro group, substitution pattern and the presence of electronwithdrawing or donating groups. From the bacterial mutagenicity studies of nitroimidazoles it is the need to identify and study the human metabolites of such compounds as potential mutagens [49]. Since mutagenicity is an undesirable property in clinically used drugs and raises the question of their potential carcinogenicity, further research is needed in order to evaluate nitroimidazole effect on DNA, contributing to the elucidation of mechanisms involved in these processes. A nitro derivative possessing good pharmacological activity with no mutagenicity would be of great interest not only from a safety point of view, but 
would also provide a basis for further investigations of the mode of action and mechanism of expression of mutagenicity.

\section{Author's Statement}

\section{Competing Interests}

The author declares no conflict of interest.

\section{References}

[1] Celik A, Aras Ates N.

The frequency of sister chromatid exchanges in cultured human peripheral blood lymphocyte treated with metronidazole in vitro.

Drug Chem Toxicol. 2006; 29: 85-94.

doi:10.1080/01480540500408663

[2] Upcroft JA, Campbell RW, Benakli K, Upcroft P and Vanelle P.

Efficacy of new 5-nitroimidazoles against metronidazole-susceptible and -resistant Giardia,

Trichomonas, and Entamoeba spp.

Antimicrob Agents Chemother. 1999; 43: 73-76.

PMid:9869568

[3] Adams GE.

Redox, radiation and reductive bioactivation.

Radiat Res. 1992; 132: 129-139.

doi: $10.2307 / 3578516$

[4] Adams GE and Stratford IJ.

Hypoxia-mediated nitroheterocyclic drugs in the radio- and chemotherapy of cancer.

Biochem Pharmacol. 1986; 35: 71-76.

doi:10.1016/0006-2952(86)90560-5

[5] Adams GE and Stratford IJ.

Bioreductive drugs for cancer therapy: the search for tumor specificity.

Int J Radiat Oncol Biol Phys. 1994; 29: 231-238.

PMid:8195012

[6] Kapoor VK, Chadha R, Venisetty PK, Prasanth S.

Medicinal significance of nitroimidazoles: Some recent advances.

J Sci Ind Res (India). 2003; 62: 659-665.

[7] Nagarajan K, Shankar RG, Rajappa S, Shenoy ST, Costa-Pereira R.

Nitroimidazoles XXI 2,3-dihydro-6-nitroimidazo [2,1-b] oxazoles with anti-tubercular activity.

Eur J Med Chem. 1989; 24: 631-633.

doi:10.1016/0223-5234(89)90034-2

[8] Gunay NS, Capan G, Ulusoy N, Ergenc N, Otuk G, Kaya D.

5-Nitroimidazole derivatives as possible antibacterial and antifungal agents.

Farmaco. 1999; 54: 826-831.

doi:10.1016/S0014-827X(99)00109-3

[9] Silvestri R, Artico M, De Martino G, Ragno R, Massa S, Loddo R, Murgioni C, Loi AG, LaColla P, Pani A.

Synthesis, biological evaluation, and binding mode of novel 1-[2-(diarylmethoxy)ethyl]-2-methyl-5nitroimidazoles targeted at the HIV-1 reverse transcriptase.

J Med Chem. 2002; 45: 1567-1576.

doi:10.1021/jm010904a 
[10] Silvestri R, Artico M, Massa S, Marceddu T, DeMontis F, LaColla P.

1-[2-(Diphenylmethoxy)ethyl]-2-methyl-5-nitroimidazole a potent lead for the design of novel NNRTIs.

Bioorg Med Chem Lett. 2000; 10: 253-256.

doi:10.1016/S0960-894X(99)00664-2

[11] Hodgkiss RJ.

Use of 2-nitroimidazoles as bioreductive markers for tumour hypoxia.

Anticancer Drug Res. 1998; 13: 687-702.

PMid:9755725

[12] Hori H, Jin CZ, Kiyono M, Kasai S, Shimamura M, Inayama S.

Design, synthesis, and biological activity of anti-angiogenic hypoxic cell radiosensitizer

haloacetylcarbamoyl-2-nitroimidazoles.

Bioorg Med Chem. 1997; 5: 591-599.

doi:10.1016/S0968-0896(96)00274-X

[13] Kasai S, Nagasawa H, Yamashita M, Masui M, Kuwasaka H, Oshodani T, Uto Y, Inomata T, Oka S, Inayamata S, Hori H.

New antimetastatic hypoxic cell radiosensitizers: design, synthesis, and biological activities of 2nitroimidazole-acetamide, TX-1877, and its analogues.

Bioorg Med Chem. 2001; 9: 453-464.

doi:10.1016/S0968-0896(00)00265-0

[14] Petray PB, Morilla MJ, Corral RS, Romero EL.

In vitro activity of Etanidazole against the protozoan parasite Trypanosoma cruzi.

Mem Inst Oswaldo Cruz. 2004; 99: 233-235.

doi:10.1590/S0074-02762004000200021

[15] Petray PB, Morilla MJ, Corral RS, Romero EL.

In vitro activity of Etanidazole against the protozoan parasite Trypanosoma cruzi.

Mem Inst Oswaldo Cruz. 2004; 99: 233-235.

doi:10.1590/S0074-02762004000200021

[16] Maeda K, Osata T, Umezawa H.

A new antibiotic, azomycin.

J Antibiot. 1953; 6: 182.

PMid:13152032

[17] Cosar C, Julou L.

Activite'de I (hydroxy-2-ethyl)-1-methyl-2-nitro-5 imidazole (8,823 R.P.) vis-a`-vis des infections experimentales Trichomonas vaginalis.

Ann Inst Pasteur. 1959; 96: 238-241.

PMid:13627590

[18] Schneider J.

Traitment de la giardiase (lambliase) par le metronidazole.

Bull Soc Pathol Exot Filiales. 1961; 54: 84-93.

PMid:13748230

[19] Powell SJ, Macleod L, Wilmot AJ, Elsdon-Dew R.

Metronidazole in amoebic dysentery and amoebic liver abscess.

Lancet. 1966; 288: 1329-1331.

doi:10.1016/S0140-6736(66)92081-2

[20] Garcia-Leverde A, De Bonila L.

Clinical trials with metronidazole in human balantidiasis.

Am J Trop Med Hyg. 1975; 24: 781-783.

PMid:1190365

[21] Townson SM, Boreham PFL, Upcroft P, Upcroft JA.

Resistance to the nitroheterocyclic drugs.

Acta Trop. 1994; 56: 173-194.

doi:10.1016/0001-706X(94)90062-0 
[22] Stanley. SL Jr.

Amoebiasis.

Lancet. 2003; 361: 1025-1034.

doi:10.1016/S0140-6736(03)12830-9

[23] Haque R, Huston CD, Hughes M, Houpt E, Petri WA Jr.

Amoebiasis.

N Engl J Med. 2003; 348: 1565-1573.

doi:10.1056/NEJMra022710

[24] Müller M.

Mode of action of metronidazole on anaerobic bacteria and protozoa.

Surgery. 1983; 93: 165-171.

PMid:6849201

[25] Edwards DI.

Reduction of nitroimidazoles in vitro and DNA damage.

Biochem Pharmacol. 1986; 35: 53-58.

doi:10.1016/0006-2952(86)90554-X

[26] Petri WA Jr.

Therapy of intestinal protozoa.

Trends Parasitol. 2003; 19: 523-526.

doi:10.1016/j.pt.2003.09.003

[27] Legator MS, Connor TH, Stoeckel M.

Detection of mutagenic activity of metronidazole and niridazole in body fluids of humans and mice. Science. 1975; 188: 1118-1119. doi:10.1126/science.766186

[28] Rustia M, Shubik P.

Induction of lung tumors and malignant lymphomas in mice by metronidazole.

J Natl Cancer Inst. 1972; 48: 721-729.

PMid:5058971

[29] Shubik P.

Current status of chemical carcinogenesis.

Proc Natl Acad Sci U S A. 1972; 69: 1052-1055.

doi:10.1073/pnas.69.4.1052

[30] Boyer $\mathrm{JH}$.

Nitroazoles.

VCH Publishers, Inc., Deerfield Beach, FL, 1986: 165-166 and references cited therein.

[31] Goldman P.

The development of 5-nitroimidazoles for the treatment and prophylaxis of anaerobic bacterial infections.

J Antimicrob Chemother. 1982; 10 (Suppl.): A23-A33.

doi:10.1093/jac/10.suppl_A.23

[32] Nagarajan K, Arya VP, George T, Sudarsanam V, Shah RK, Goud AN, Shenov SJ, Honkan V, Kulkarni YS and Rao ML.

Nitroimidazoles. IV. 1-1-Methyl-5-nitroimidazolyl (2)-2-oxo-3-sulphonyl (carbamoylthiocarbamoyl) tetrahydro imidazoles.

Ind J Chem. 1982; 21: 928-940.

[33] Ray DK, Chatterjee DK, Tendulkar JS.

Comparative efficacy of GO 10213 and some nitroimidazoles against Trichomonas vaginalis and $T$. foetus in mice infected subcutaneously.

Ann Trop Med Parasitol. 1982; 76: 175-178.

PMid:6979983 
[34] Ray DK, Tendulkar JS, Shrivastava VB, Datta AK, Nagarajan K.

A metronidazole-resistant strain of Trichomonas vaginalis and its sensitivity to GO 10213.

J Antimicrob Chemother. 1984; 14: 423-426.

doi:10.1093/jac/14.4.423

[35] Hof H, Stroder J.

Antibacterial activity of GO 10213, a nitroimidazole derivative.

Antimicrob Agents Chemother. 1986; 29: 953-954.

PMid:3729357

[36] Shafiee A, Sayadi A, Roozbahani MH, Foroumadi A, Kamal F.

Synthesis and in vitro antimicrobial evaluation of 5-(1-methyl-5-nitro-2-imidazolyl)-4H-1, 2, 4-triazoles.

Arch Pharm. 2002; 335: 495-499.

doi:10.1002/ardp.200290004

[37] Bagan ES, Miwa GT.

Uniquely non-mutagenic substituted nitroimidazole.

1988 US 4,728,664.

[38] Miwa GT, Wang Wen-Jen R, Walsh JS.

Non-mutagenic 1,2-disubstituted-4-nitroimidazole compounds useful as antiprotozoal agents. 1987 US 4,675, 337.

[39] Scalesiani JBA, Calle YB.

1-Methyl-5-nitro-imidazoline derivatives and therapeutic compositions which contain them as active principle.

1983 EP 0103100-A (8413).

[40] Walsh JS, Wang R, Bagan E, Wang CC, Wislocki P, Miwa GT.

Structural alterations that differentially affect the mutagenic and antitrichomonal activities of 5nitroimidazoles.

J Med Chem 1987; 30: 150-156.

doi:10.1021/jm00384a025

[41] Tessitore PT.

New 2-(1-alkyl-5-nitro)-imidazolyl-1-(2-hydroxy-5-alkyl)-phenyl carbinols, method for the preparation thereof and pharmaceutical compositions containing them. 1983 EP $111,657$.

[42] Fudan D.

Antibacterial 5-Nitro-1-methyl-imidazolyl-3-terbutyl-2-hydroxy-aryl-carbinols.

(Euroresearch S.R.L.). 1992 EP 535,528.

[43] Arredondo Y, Moreno-Mafias M, Pleixats R, Palacin C, Raga MM, Castelló JM, Ortiz JA.

Preparation, antimicrobial evaluation and mutagenicity of differently substituted [2-hydroxyaryl]-[1methyl-5-nitro-1H-2-imidazolyl]methanols.

Bioorg Med Chem Lett. 1996; 6: 1781-1784.

doi:10.1016/0960-894X(96)00317-4

[44] Dubini F, Riviera L, Cocuzza C, Bellotti MG.

Antibacterial, antimycotic and trichomonicidal activity of a new nitroimidazole EU 11100.

J Chemother. 1992; 4: 342-346.

PMid:1287136

[45] Hadj-esfandiari N, Navidpour L, Shadnia H, Amini M, Samadi N, Faramarzi MA \& Shafieea A. Synthesis, antibacterial activity, and quantitative structure-activity relationships of new (Z)-2(nitroimidazolylmethylene)-3(2H)-benzofuranone derivatives.

Bioorg Med Chem Lett. 2007; 17: 6354-6363.

doi:10.1016/j.bmcl.2007.09.062

[46] Khabnadideh S, Rezaei Z, Khalafi-Nezhad A, Bahrinajafi R, Mohamadi R, Farrokhroz AA.

Synthesis of $\mathrm{N}$-alkylated derivatives of imidazole as antibacterial agents.

Bioorg Med Chem Lett. 2003; 13: 2863-2865.

doi:10.1016/S0960-894X(03)00591-2 
[47] Crozet MD, Botta C, Gasquet M, Curti C, Rémusat V, Hutter S, Chapelle O, Azas N, De Méo M, Vanelle $P$.

Lowering of 5-nitroimidazole's mutagenicity: Towards optimal antiparasitic pharmacophore.

Eur J Med Chem. 2009; 44: 653-659.

doi:10.1016/j.ejmech.2008.05.015

[48] Hrelia P, Fimognari C, Maffei F, Brighenti B, Garuti L, Burnelli S, Cantelli-Forti G.

Synthesis, metabolism and structure-mutagenicity relationships of novel 4-nitro-(imidazoles and pyrazoles) in Salmonella typhimurium.

Mutat Res. 1998; 397: 293--301.

doi:10.1016/S0027-5107(97)00229-7

[49] Purohit V, Basu AK.

Mutagenicity of nitroaromatic compounds.

Chem Res Toxicol. 2000; 8: 673-692.

doi:10.1021/tx000002x

[50] De Méo M, Vanelle P, Bernadini E, Laget M, Maldonado J, Jentzer O, Crozet MP, Duménil G. Evaluation of the mutagenic and genotoxic activities of 48 nitroimidazoles and related imidazole derivates by the Ames test and the SOS chromotest.

Environ Mol Mutagen. 1992; 19: 167-181.

PMid:1541258

[51] Dobiás L, Cerná M, Rössner $P$, Srám R.

Genotoxicity and carcinogenicity of metronidazole.

Environ Mutagen. 1994; 317: 177-194.

Pmid:7515153

[52] Mirzaei J, Siavoshi F, Emami S, Safari F, Khoshayand MR, Shafiee A, Foroumadi A. Synthesis and in vitro anti-Helicobacter pylori activity of N-[5-(5-nitro-2-heteroaryl)-1,3,4-thiadiazol-2-yl]thiomorpholines and related compounds.

Eur J Med Chem. 2008; 43: 1575-1580.

doi:10.1016/j.ejmech.2007.11.019

[53] Dunn LA and Boreham PFL.

The in-vitro activity of drugs against Blastocystis hominis.

J Antimicrob Chemother. 1991; 27: 507-516.

doi:10.1093/jac/27.4.507

[54] Gunay NS, Capan G, Ulusoy N, Ergenc N, Otuk G and Kaya D.

Nitroimidazole derivatives as possible antibacterial and antifungal agents.

Farmaco. 1999; 54: 826-831.

doi:10.1016/S0014-827X(99)00109-3

[55] Sun $Z$ and Zhang $Y$.

Antituberculosis activity of certain antifungal and antihelmintic drugs.

Tub Lung Dis. 1999; 79: 319-320.

doi:10.1054/tuld.1999.0212

[56] Olender D, Zwawiak J, Lukianchuk V, Lesyk R, Kropacz A, Fojutowski A, Zaprutko L.

Synthesis of some $\mathrm{N}$-substituted nitroimidazole derivatives as potential antioxidant and antifungal agents.

Eur J Med Chem. 2009; 44: 645-652.

doi:10.1016/j.ejmech.2008.05.016

[57] Cavalleri B, Ballotta R, Arioli V, Lancini G.

New 5-substituted 1-alkyl-2-nitroimidazoles.

J Med Chem. 1973; 16: 557-560.

doi:10.1021/jm00263a035 
[58] Cavalleri B, Volpe G, Arioli V.

Synthesis and biological activity of some vinyl-substituted 2-nitroimidazoles.

J Med Chem. 1977; 20: 656-660.

doi:10.1021/jm00215a007

[59] Cavalleri B, Volpe G, Arioli V, Parenti F.

Synthesis and biological activity of some 2-aminoimidazoles.

Arzneimittelforschung. 1977; 27: 1889-1895.

PMid:579099

[60] Cavalleri B, Volpe G, Ripamonti A, Arioli V.

1-Methyl-2-nitroimidazol-5-yl derivatives. IIIrd communication.

Arzneimittelforschung. 1977; 27: 1131-1134.

PMid:578425

[61] Cavalleri B, Volpe G, Arioli V, Lancini GC.

1-Methyl-2-nitroimidazol-5-yl derivatives. IVth Communication.

Arzneimittelforschung. 1977; 27: 1391-1392.

PMid:332192

[62] Sehgal RK, Agrawal KC.

Novel nitroimidazo[2,1-b] oxazole formation from reaction of 2, 4(5)-dinitroimidazole with oxiranes (1). J Heterocyclic Chem. 1979; 16: 1499-1500.

doi:10.1002/jhet.5570160743

[63] Ashtekar DR, Costa-Perira R, Nagrajan K, Vishvanathan N, Bhatt AD, Rittel W.

In vitro and in vivo activities of the nitroimidazole CGI 17341 against Mycobacterium tuberculosis.

Antimicrob Agents Chemother. 1993; 37: 183-186.

PMid:8452346

[64] Li X, Manjunatha UH, Goodwin MB, Knox JE, Lipinski CA, Keller TH, Barry CE III and Dowd CS. Synthesis and antitubercular activity of 7-(R)- and 7-(S)-methyl-2-nitro-6-(S)-(4-

(trifluoromethoxy)benzyloxy)-6,7-dihydro-5H-imidazo[2,1-b][1,3]oxazines, analogues of PA-824.

Bioorg Med Chem Lett. 2008; 18: 2256-2262.

doi:10.1016/j.bmcl.2008.03.011

[65] Matsumoto M, Hashizume H, Tomishige T, Kawasaki M, Tsubouchi H, Sasaki H, Shimokawa Y, Komatsu M.

OPC-67683, a Nitro-Dihydro-Imidazooxazole derivative with promising action against tuberculosis in vitro and in mice.

PLoS Med. 2006; 3: 2131-2144.

doi:10.1371/journal.pmed.0030466

[66] Stover CK, Warrener P, VanDevanter DR, Sherman DR, Arain TM, Langhorne MH, Anderson SW, Towell JA, Yuan Y, McMurray DN, Kreiswirth BN, Barry CE III, Baker WR.

A small-molecule nitroimidazopyran drug candidate for the treatment of tuberculosis.

Nature. 2000; 405: 962-966.

doi:10.1038/35016103

[67] Barry CE III, Boshoff HI, Dowd CS.

Prospects for clinical introduction of nitroimidazole antibiotics for the treatment of tuberculosis.

Curr Pharm Des. 2004; 10: 3239-3262.

doi: $10.2174 / 1381612043383214$

[68] Jackson CJ, Lamb DC, Kelly DE, Kelly SL.

Bactericidal and inhibitory effects of azole antifungal compounds on Mycobacterium smegmatis.

FEMS Microbiol Lett. 2000; 192: 159-162.

doi:10.1111/j.1574-6968.2000.tb09375.x 
[69] Mamolo MG, Zampieri D, Falagiani V, Vio L, Banfi E.

Synthesis and antifungal activity of (+/-)-1-(5-aryl-3-pyridin-2-yl-4,5-dihydro-pyrazol-1-yl)-2-imidazol-1yl-ethanone. derivatives.

Farmaco. 2003; 58: 315-322.

doi:10.1016/S0014-827X(02)00006-X

[70] Walczak K, Gondela A, Suwinski J.

Synthesis and anti-tuberculosis activity of $N$-aryl-C-nitroazoles.

Eur J Med Chem. 2004; 39: 849-853.

doi:10.1016/j.ejmech.2004.06.014

[71] Foroumadi A, Soltani F, Jabini R, Moshafi MH, Rasnani FM.

Antituberculosis Agents X. Synthesis and evaluation of in vitro antituberculosis activity of 2-(5-nitro-2furyl)- and 2-(1-methyl-5-nitro-1H-imidazol-2-yl)-1,3,4-thiadiazole Derivatives.

Arch Pharm Res. 2004; 27: 502-506.

doi:10.1007/BF02980122

[72] Foroumadi, A.; Mirzaei, M.; Shafiee A.

Antituberculosis agents II: Evaluation of in vitro antituberculosis activity and cytotoxicity of some 2-(1methyl-5-nitro-2-imidazolyl)-1,3,4-thiadiazole derivatives.

Farmaco. 2001; 56: 621-623.

doi:10.1016/S0014-827X(01)01099-0

[73] Buschini A, Giordani F, Northfleet de Albuquerque C, Pellacani C, Pelosi G, Rossi C, Araujo TM, Zucchi D, Poli P.

Trypanocidal nitroimidazole derivatives: Relationships among chemical structure and genotoxic activity.

Biochem Pharmacol. 2007; 73: 1537-1547.

doi:10.1016/j.bcp.2007.01.024

[74] Bouteille B, Marie-Daragon A, Chauvie're G, De Albuquerque C, Enanga B, Darde M-L et al. Effect of megazol on Trypanosoma brucei brucei acute and subacute infections in Swiss mice.

Acta Trop. 1995; 60: 73-80.

doi:10.1016/0001-706X(95)00109-R

[75] Enanga B, Keita M, Chauviere G, Dumas M, Bouteille B.

Megazol combined with suramin: a chemotherapy regimen which reversed the CNS pathology in a model of human African trypanosomiasis in mice.

Trop Med Int Health. 1998; 3: 736-741.

PMid:9754669

[76] Viode C, Bettache N, Cenas N, Krauth-Siegel RL, Chauviere G, Bakalara N et al.

Enzymatic reduction studies of nitroheterocycles.

Biochem Pharmacol. 1999; 57: 549-557.

doi:10.1016/S0006-2952(98)00324-4

[77] Chauviere G, Bouteille B, Enanga B, de Albuquerque C, Croft SL, Dumas M et al.

Synthesis and biological activity of nitro heterocycles analogous to megazol, a trypanocidal lead.

J Med Chem. 2003; 46: 427-440.

doi:10.1021/jm021030a

[78] Voogd CE, Van der Stel JJ, Jacobs JJ.

The mutagenic action of nitroimidazoles. II. Effects of 2-nitroimidazoles.

Mutat Res. 1975; 31: 149-152.

doi:10.1016/0165-1161(75)90083-7

[79] Melo ME, Ferreira LC.

Screening the mutagenic activities of commonly used antiparasite drugs by the Simultes, a simplified Salmonella/microsome plate incorporation assay.

Rev Inst Med Trop Sao Paulo. 1990; 32: 269-274.

doi:10.1590/S0036-46651990000400006 
[80] Bouteille B, Chauvie're G.

Implication du megasol dans la chimiotherapie des trypanosomosis.

Med Trop. 1999; 59: 321-330.

PMid: 10816740

[81] Docampo R, Moreno SN.

Free radical metabolites in the mode of action of chemotherapeutic agents and phagocytic cells on Trypanosoma cruzi.

Rev Infect Dis. 1984; 6: 223-238.

PMid:6328615

[82] Poli P, de Mello MA, Buschini A, Mortara RA, de Albuquerque NC, da Silva S et al.

Cytotoxic and genotoxic effects of megazol, an anti-Chagas' disease drug, assessed by different short-term tests.

Biochem Pharmacol. 2002; 64: 1617-1627.

doi:10.1016/S0006-2952(02)01390-4

[83] Nesslany F, Brugier S, Mouries MA, Le Curieux F, Marzin D.

In vitro and in vivo chromosomal aberrations induced by megazol.

Mutat Res. 2004; 560: 147-158.

doi:10.1016/j.mrgentox.2004.02.013

[84] Ferreira RC, Ferreira LC.

CL 64,855, a potent anti-Trypanosoma cruzi drug, is also mutagenic in the Salmonella/microsome assay.

Mem Inst Oswaldo Cruz. 1986; 81: 49-52.

doi:10.1590/S0074-02761986000100006

[85] Borowy NK, Nelson RT, Hirumi H, Brun R, Waithaka HK, Schwartz D, Polak A.

RO150216 a nitroimidazole compound active against human and animal pathogenic African

trypanosomes.

Ann Trop Med Parasitol. 1988; 82: 13-19.

PMid:3401068

[86] McCoy EC, Rosenkranz HR, Mermelstein R.

Evidence for the existence of a family of bacterial nitroreductases capable of activating nitrated polycyclics to mutagens.

Environ Mol Mutagen. 1981; 3: 421-427.

doi:10.1002/em.2860030403

[87] Orr JC, Bryant DW, McCalla DR, Quilliam MA.

Dinitropyrene-resistant Salmonella typhimurium are deficient in $\mathrm{n}$ acetyl-CoA-acetyl-transferase.

Chem Biol Interact. 1985; 54: 281-288.

doi:10.1016/S0009-2797(85)80169-1

[88] Erik JC, Vander Goot H, Sterk GJ, Timmerman H.

Histamine $\mathrm{H}_{2}$-receptor agonists. Synthesis, in vitro pharmacology, and qualitative structure-activity relationships of substituted 4-and 5-(2-aminoethyl) thiazoles.

J Med Chem. 1992; 35: 3239-3246.

doi:10.1021/jm00095a021

[89] Kovalainen JT, Christiaans JAM, Kotisaari S, Laitinen JT, Männistö PT, Tuomisto L, Gynther J.

Synthesis and in vitro pharmacology of a series of new chiral histamine H3-receptor ligands: 2- $(R$ and S)-amino-3-(1H-imidazol-4(5)-yl) propyl ether derivatives.

J Med Chem. 1999; 42: 1193-1202.

doi:10.1021/jm980408v

[90] Farsch SC, Nick JA, Fadok VA, Bratton DL, Worthen GS, Henson PM.

p38 Mitogen-activated protein kinase-dependent and -independent intracellular signal transduction pathways leading to apoptosis in human neutrophils.

J Biol Chem. 1998; 273: 8389-8397.

doi:10.1074/jbc.273.14.8389 
[91] Salerno L, Sorrenti V, Guerrera F, Sarva MC, Siracusa MA, Di Giacomo C, Vanella A. $\mathrm{N}$-substituted-imidazoles as inhibitors of nitric oxide synthase: a preliminary screening. Pharmazie. 1999; 54: 685-690.

[92] Castelli M, Malagoli M, Lupo L, Roffia S, Paolucci F, Cermelli C, Zanca A, Baggio G. Cytotoxicity and probable mechanism of action of sulphimidazole.

J Antimicrob Chemother. 2000; 46: 541-550. doi:10.1093/jac/46.4.541

[93] Adams GE, Clarke ED, Flockhart IR, Jacobs RS, Sehmi DS, Stratford P, Wardman IJ, Watts ME, Parrick J, Wallace RG, Smithen CE.

Structure-activity relationships in the development of hypoxic cell radiosensitizers I. Sensitization efficiency.

Int J Radiat Biol Relat Stud Phys Chem Med. 1979; 35: 133-150.

PMid:312783

[94] Noker P, Simpson-Herren L, Wagoner SD.

Distribution of nitroimidazoles and L-phenylalanine mustard in mammary adenocarcinoma 16/C tumors.

Cancer Chemother Pharm. 1987; 20: 188-192.

PMid:3677296

[95] Al-Soud YA, Al-Masoudi NA, Hassan HG, Clercq ED, Pannecouque C.

Nitroimidazoles. V. Synthesis and anti-HIV evaluation of new 5-substituted piperazinyl-4-nitroimidazole derivatives.

Acta Pharm. 2007; 57: 379-393.

doi:10.2478/v10007-007-0031-7

[96] Silvestri R, Artico M, Massa S, Marceddu T, Montis F De and Colla P La.

1-[2-(diphenylmethoxy)ethyl]-2-methyl-5-nitroimidazole: a potent lead for the design of novel NNRTIs.

Bioorg Med Chem Lett. 2000; 10: 253-256.

doi:10.1016/S0960-894X(99)00664-2

[97] Martino GDe, Regina GLa, Pasquali ADi, Ragno R, Bergamini A, Ciaprini C, Sinistro A, Maga G, Crespan E, Artico M and Silvestri R.

Novel 1-[2-(Diarylmethoxy)ethyl]-2-methyl-5-nitroimidazoles as HIV-1 Non-Nucleoside Reverse

Transcriptase Inhibitors: A structure-activity relationship investigation.

J Med Chem. 2005; 48: 4378-4388.

doi:10.1021/jm050273a

[98] Poorrajab F, Ardestani SK, Emami S, Behrouzi-Fardmoghadam M, Shafiee A, Foroumadi, A. Nitroimidazolyl-1,3,4-thiadiazole-based anti-leishmanial agents: Synthesis and in vitro biological evaluation.

Eur J Med Chem. 2009; 44: 1758-1762.

doi:10.1016/j.ejmech.2008.03.039

[99] Overgaard J.

Clinical evaluation of nitroimidazoles as modifiers of hypoxia in solid tumors.

Oncol Res. 1994; 6: 509-518.

PMid:7620219

[100] Brezden CB, McClelland RA and Rauth AM.

Mechanism of the selective hypoxic cytotoxicity of 1-methyl-2-nitroimidazole.

Biochem Pharmacol. 1994; 48: 361-370.

doi:10.1016/0006-2952(94)90108-2

[101] Koch CJ, Evans SM and Lord EM.

Oxygen dependence of cellular uptake of EF5 [2-(2-nitro-1H-imidazol-1-yl)- $N-(2,2,3,3,3-$ pentafluoropropyl)acetamide]: Analysis of drug adducts by fluorescent antibodies vs bound radioactivity.

Br J Cancer. 1995; 72: 869-874.

PMid:7547233 
[102] Taylor YC and Rauth AM.

Oxygen tension, cellular respiration, and redox state as variables influencing the cytotoxicity of the radiosensitizer misonidazole.

Radiat Res. 1982; 91: 104-123.

doi: $10.2307 / 3575819$

[103] Wardman P.

The use of nitroaromatic compounds as hypoxic cell radiosensitizers.

Curr Top Radiat Res Q. 1977; 11: 347-398.

PMid:330116

[104] Uto Y, Nagasawa H, Jin C-Zhe, Nakayama S, Tanaka A, Kiyoi S, Nakashima H, Shimamura M, Inayama S, Fujiwara T, Takeuchi Y, Uehara Y, Kirk KL, Nakata E and Hori H.

Design of antiangiogenic hypoxic cell radiosensitizers: 2-Nitroimidazoles containing a 2aminomethylene-4-cyclopentene-1,3-dione moiety.

Bioorg Med Chem. 2008; 16: 6042-6053.

doi:10.1016/j.bmc.2008.04.041

[105] Edwards DI.

Nitroimidazole drugs-action and resistance mechanisms. I. Mechanisms of action.

J Antimicrob Chemother. 1993; 31: 9-20.

doi:10.1093/jac/31.1.9

[106] Ehlhardt WJ, Beaulieu BB Jr, Goldman P.

Mammalian cell toxicity and bacterial mutagenicity of nitrosoimidazoles.

Biochem Pharmacol. 1988; 37: 2603-2606.

doi:10.1016/0006-2952(88)90252-3

[107] Roe FJ.

Metronidazole: review of uses and toxicity.

J Antimicrob Chemother. 1977; 3: 205-212.

doi:10.1093/jac/3.3.205

[108] Roe FJ.

Toxicologic evaluation of metronidazole with particular reference to carcinogenic, mutagenic, and teratogenic potential.

Surgery. 1983; 93: 158-164.

PMid:6336861

[109] Roe FJ.

Safety of nitroimidazoles.

Scand J Infect Dis Suppl. 1985; 46: 72-81.

PMid:3865353

[110] Voogd CE.

On the mutagenicity of nitroimidazoles.

Mutat Res. 1981; 86: 243-277.

PMid:6457989

[111] Mason RP, Josephy PP.

Free radical mechanisms of nitroreductase.

In: D. E. Rickert (Ed.).

Toxicity of Nitroaromatic Compounds, Hemisphere, Washington DC, 1985: 121-140.

[112] Lindmark DG, Muller M.

Antitrichomonad action, mutagenicity, and reduction of metronidazole and other nitroimidazoles.

Antimicrob Agents Chemother. 1976; 10: 476-482.

PMid:791102

[113] Biaglow JE, Varnes ME, Roizin-Towle L, Clark EP, Epp ER, Astor MB and Hall EJ.

Biochemistry of reduction of nitro heterocycles.

Biochem Pharmacol. 1986; 35: 77-90.

doi:10.1016/0006-2952(86)90561-7 